Acta vet. scand. 1989, 30, 363-365.

Brief Communication

\title{
The In Vivo Lipolytic Effect of Salmonella typhimurium Endotoxin
}

The acute phase responses to infection and endotoxaemia include reductions in the circulating levels of $\mathrm{Fe}, \mathrm{Zn}$ and $\mathrm{Ca}$. Most responses are postulated to be mediated by the cytokines interleukin - 1 (Il - 1) and tumor necrosis factor (TNF) which both are produced by monocytes and macrophages.

The mechanisms behind the hypoferraemia are well studied and it is generally accepted that the primary event is an increased granulocyte release of lactoferrin which chelate $\mathrm{Fe}$ from transferrin. The complex is then taken up by the liver (Goldblum et al. 1987).

Also $\mathrm{Zn}$ is taken up by the liver though by a different mechanism. Sankari \& Pekkanen (1982) reported a remarkable increase in hepatic $\mathrm{Zn}$ content after injection of endotoxin.

The rapid redistribution of trace elements is considered to be a defence mechanism against invading bacteria which need e. g. Fe for their growth.

The mechanisms behind the decrease in serum $\mathrm{Ca}$ are less understood. Injection of endotoxin causes a rapid increase in the blood level of prostaglandin $\mathrm{F}_{2 \alpha}\left(\mathrm{PGF}_{2 \alpha}\right)$. Intravenous infusion of $\mathrm{PGs}$, especially $\mathrm{PGE}_{2}$, is shown to induce hypocalcaemia in dairy cows (Luthman et al. 1983). However, when PG release was completely blocked by flunixin meglumin, a potent cyclo-oxygenase inhibitor, hypocalcaemia still occurred in endotoxin-treated calves (Luthman et al. 1989). It was concluded from this study that endotoxin-induced hypocalcaemia was not mediated by PGs.

The most potent stimulus for release of TNF is bacterial endotoxin. TNF is shown to have a potent lipolytic effect in adipocytes in vitro (Kawakami et al. 1987). The main purpose of the present investigation was to study the relationship between lipolysis and hypocalcaemia in endotoxin-treated calves, since it is earlier known that heavy lipolysis is associated with hypocalcaemia. Lipolysis-induced hypocalcaemia in rabbits and sheep has been described by several authors. Akgün \& Rudman (1969) showed e.g. that hormone-induced lipolysis in rabbits was associated with uptake of $\mathrm{Ca}$ in adipose tissue of an order sufficient to explain the reduction of the serum level.

Five calves with a mean weight of about 60 $\mathrm{kg}$ were used in the study. All animals were of the SRB breed.

The animals were given an intravenous injection of Salmonella typhimurium endotoxin at a dose of $0.2 \mu \mathrm{g} / \mathrm{kg}$. The endotoxin preparation was of the same batch as was used in several other studies (e. g. Fredriksson 1984). The methods of purification of the preparation was earlier described by Fredriksson.

Blood was sampled at intervals shown in Fig. 1 for analysis of $\mathrm{Ca}, \mathrm{Fe}, \mathrm{Zn}$ and free fatty acids (FFA).

All animals showed very obvious clinical signs: increased salivation, forced breathing, ruminal stasis and unwillingness to move. The injection was followed by the expected fall in the serum levels of $\mathrm{Fe}$ and $\mathrm{Zn}$. The $\mathrm{Fe}$ level decreased from a preinjection mean of $33.3 \pm 5.4 \mu \mathrm{mol} / 1$ to $11.4 \pm 4.9 \mu \mathrm{mol} / \mathrm{l}$. The lowest level occurred after $24 \mathrm{~h}$. $\mathrm{Zn}$ fell from $19.3 \pm 1.5$ to $5.5 \pm 0.6 \mu \mathrm{mol} / 1$ after 8 h. 


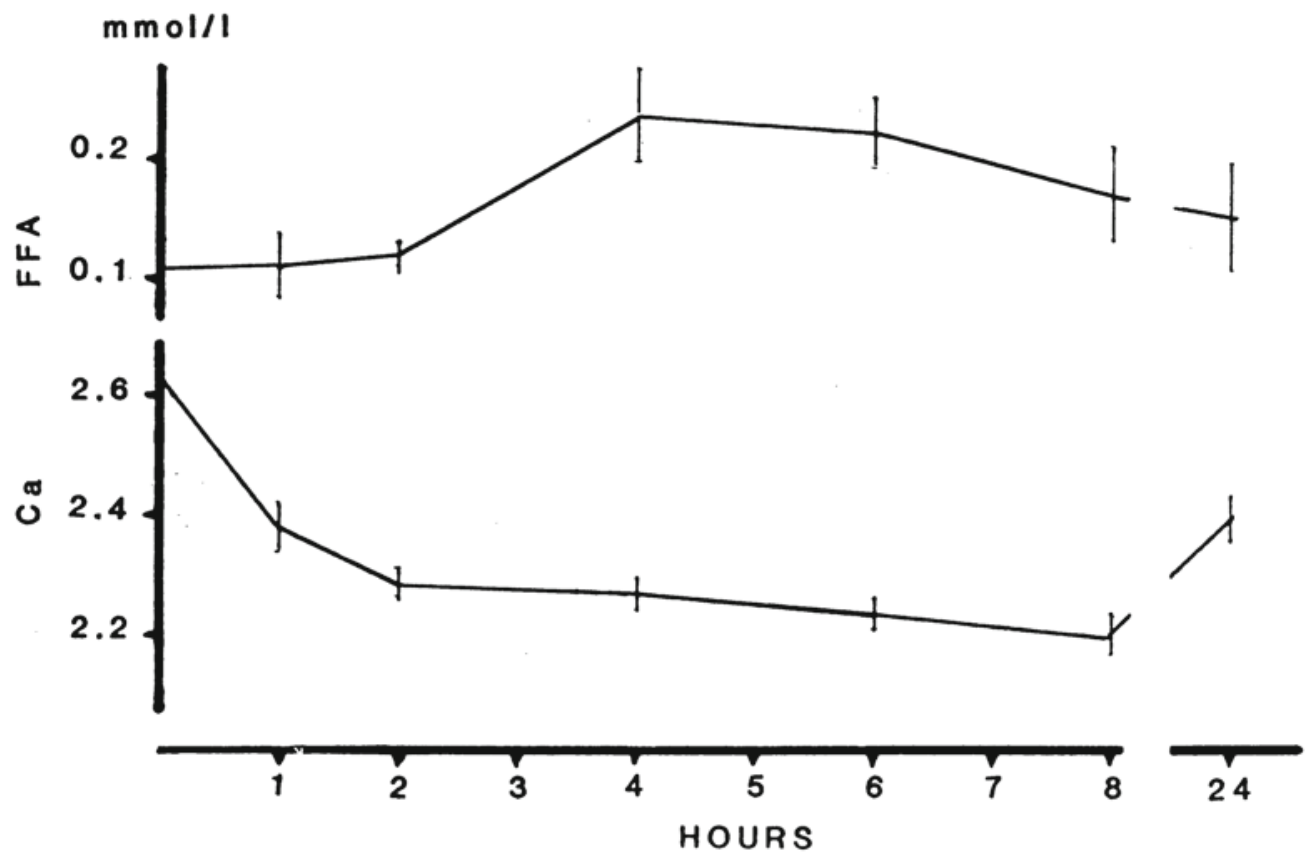

Figure 1. Changes in the serum levels of calcium and free fatty acids in calves after injection of $0.2 \mu \mathrm{g} / \mathrm{kg}$ of Salmonella typhimurium endotoxin. $\mathrm{n}=5, \overline{\mathrm{x}} \mathrm{SD}$.

It seems clear from earlier studies that heavy lipolysis (FFA levels of at least $2 \mathrm{mmol} / \mathrm{l}$ ) is required to reduce serum Ca $(A k g u ̈ n \& R u d-$ man 1969, Luthman \& Holtenius 1972). As shown in Fig. 1 there was a very slight increase in serum FFA and $\mathrm{Ca}$ decreased before any increase in FFA could be observed. The slight decline in $\mathrm{Ca}$ was therefore probably not lipolysis-induced.

As described previously endotoxin injection causes a rapid increase in the blood levels of $\mathrm{PGF}_{2 \alpha}$. Peak levels usually occurs after 1-2 h. PGs show a potent antilipolytic effect and it may be possible that the lipolytic effect of TNF was blocked by PG.

The mechanisms behind the endotoxin-induced decrease in serum $\mathrm{Ca}$ remains unclear, a possibility is that $\mathrm{Ca}$ is redistributed in a manner similar to $\mathrm{Zn}$ and $\mathrm{Fe}$.
Jan Luthman and Björn Bengtsson, Department of Cattle and Sheep Diseases, Swedish University of Agricultural Sciences, Uppsala, Sweden.

\section{References}

Akgün S, Rudman D: Relationship between the mobilization of free fatty acids from adipose tissue, and the concentration of calcium in the extra-cellular fluid and in the tissue. Endocrinology 1969, 84, 926-930.

Fredriksson G: Prostaglandins, endotoxins and uterine bacteriology in reproduction of the doe and cow. Thesis, Uppsala 1984.

Goldblum SE, Cohen DA, Jay M, McClain J: Interleukin-1 induced depression of iron and zinc: role of granulocytes and lactoferrin. Amer. J. Physiol. 1987, 252, E27-E32. 
Kawakami M, Murase T, Ogawa H, Ishibashi S, Mori $N$, Takaku F, Shibata $S$ : Human recombinant TNF suppresses lipoprotein lipase activity and stimulates lipolysis in 3T3 - L1 cells. J. Biochem. 1987, 101, 331-338.

Luthman J, Holtenius P: Norepinephtine-induced fatty liver and hypocalcaemia in sheep. Acta vet. scand. 1972, 13, 31-35.

Luthman J. Kindahl H, Jacobsson SO: Influence of prostaglandins on calcium homeostasis in dairy cows. J. Vet. Med. A, 1983, 30, 521525 .
Luthman J, Kindahl H, Jacobsson SO: The influence of flunixin on the response to Salmonella typhimurium endotoxin in calves. Acta vet. scand. 1989, 30, 295-300.

Sankari S, Pekkanen T: The effect of endotoxin on the liver lipid peroxid levels and on the liver and plasma zinc concentration in rats as related to time after administration. Acta vet. scand. 1982, 23, 24-29.

\section{(Received November 7, 1989; accepted December 1, 1989).}

Reprints may be requested from: Jan Luthman, Department of Cattle and Sheep Diseases, Swedish University of Agricultural Sciences, S-750 07 Uppsala, Sweden. 
